\title{
Determination of Some Quality Parameters of White Cheeses Produced from Different Animal Milks During Storage
}

\author{
Farklı Hayvan Sütlerinden Üretilen Beyaz Peynirlerin Depolama Süresince Bazı Kalite \\ Parametrelerinin Belirlenmesi
}

\author{
Mubin KOYUNCU*', , Yusuf TUNÇTÜRK ${ }^{2, b}$ \\ ${ }^{1}$ Research Center for Redox Applications in Foods I Ĭgdr University, I $\breve{g} d ı r$, Turkey \\ ${ }^{2}$ Department of Food Engineering Faculty of Engineering Yüzüncü Yll University, Van, Turkey
}

\author{
• Geliş tarihi / Received: 07.01.2020 • Düzeltilerek geliş tarihi / Received in revised form: 06.05.2020 • Kabul tarihi / Accepted: 20.05 .2020
}

\begin{abstract}
In this study, some physicochemical properties of white cheeses produced from different animal milk (bovine, ovine, caprine) were investigated during storage. Some chemical, biochemical and electrophoretic analyzes were performed on cheese samples on the 3rd, 30th, 60th, 120th and 180th days of storage. Sensory analyzes were made on the 180th day of ripening period. Significant differences were determined in fat $(\mathrm{p}<0.05)$, protein $(\mathrm{p}<0.01)$ and cheese yield $(\mathrm{p}$ $<0.01$ ) of White cheese samples produced from bovine, ovine and caprine milk. The $\mathrm{pH}$ values of ovine and caprine cheeses were found higher. WSN and TCA-SN values were revealed to be higher in sheep and caprine cheeses than bovine cheeses $(p<0.01)$. However, there was no difference between the cheese samples in terms of PTA-SN values. At the end of the ripening period, cheeses made from caprine milk reached the highest Acid Degree Value (ADV) values, followed by ovine and bovine milk cheeses $(\mathrm{p}<0.01)$. Both $\alpha \mathrm{S}$-casein and $\beta$-casein were more hydrolyzed in ovine cheese samples, followed by caprine and bovine cheese samples, respectively. As a result of sensory analysis, it was determined that ovine cheeses received higher scores than bovine and caprine cheese samples, and cheeses made from bovine milk are given low scores by panelists in terms of taste and flavor.
\end{abstract}

Keywords: Lipolysis, Proteolysis, Ripening, White Cheese

$\ddot{O}_{z}$

Bu çalışmada, farklı hayvan sütlerinden (inek, koyun, keçi) üretilen Beyaz peynirlerin depolama süresince bazı fizikokimyasal özellikleri araştırllmıştır. Depolamanın 3., 30., 60., 120. ve 180. günlerinde peynir örneklerinde bazı kimyasal, biyokimyasal ve elektroforetik analizler gerçekleştirilmiştir. Duyusal analizler olgunlaşma süresinin 180. gününde yapılmıştır. Inek, koyun ve keçi sütlerinden üretilen Beyaz peynir örneklerinde yă̆ $(p<0.05)$, protein $(p$ $<0.01)$ ve peynir randımanı $(p<0.01)$ açısından önemli farklılıklar belirlenmiştir. Koyun ve keçi peynirlerinin $p H$ değerleri daha yüksek değerde bulunmuştur. WSN ve TCA-SN değerleri koyun ve keçi peynirlerinde inek peynirlerinden daha yüksek olduğu ortaya konulmuştur ( $<<0.01)$. Bununla birlikte, PTA-SN değerleri açısından peynir örnekleri arasında bir farklılık tespit edilmemiştir. Olgunlaşma süresinin sonunda, keçi sütünden üretilen peynirler en yüksek Acid Degree Value (ADV) değerlerine ulaşmış ve bunu koyun ve inek sütü peynirleri izlemiştir $(p<0.01)$. Hem $\alpha S$ kazein hem de $\beta$-kazein, koyun peyniri örneklerinde daha fazla hidrolize edilmiş ve bunu strasıyla keçi ve inek peynir örnekleri izlemiştir. Duyusal analizler sonucunda, koyun peynirlerinin inek ve keçi peynir örneklerinden daha yüksek puanlar aldığı ve inek sütünden üretilen peynirlere panelistler tarafindan tat ve lezzet açısından düşük puanlar verildiği de ortaya konulmuştur.

Anahtar kelimeler: Lipoliz, Proteoliz, Olgunlaştırma, Beyaz Peynir

\footnotetext{
*a Mubin KOYUNCU; mubin.koyuncu@igdir.edu.tr, Tel: (0476) 2230010 (3400), orcid.org/0000-0003-1798-8943

b orcid.org/0000-0001-5240-200X
} 


\section{Introduction}

In the last three decades, world milk production has increased by more than 58 percent, from 522 million tons in 1987 to 828 million tons in 2017. Only $2 \%$ of the world milk production is obtained from goats, and $1 \%$ from sheep (FAO, 2019). However, especially in last decade caprine milk production has been increasing in both developing and developed countries. Ovine milk has been increasing only in developing countries (Boyazoglu, 2002; Pirisi et al,. 2011; Stocco et al., 2018). Sheep and goats are seasonal polyestric animals and their births take place in Eastern Turkey in February-March. Sheep are usually milked in May and August, and $40 \mathrm{~kg}$ of milk is obtained during a lactation period (Y1ldiz and Denk, 2006). Goats are milked for a longer period and lactation milk yields are reported as 140-150 $\mathrm{kg}$ (Şimşek et al., 2006). Ovine milk is richer in protein and fat than bovine and caprine milk. Hairy goat is our domestic goat breed and it produces milk with a richer composition compared to culture breed goats like Saanen. Milk production is over 22 million tons per year in Turkey at 2018, in which ovine milk has the proportion of $6.5 \%$ and caprine milk $2.5 \%$ (URL-1). Turkey has an important potential in terms of ovine and caprine milk production, which are especially preferred for White cheese making. High cheese yield is the other factor for Turkish producers.

White-pickled cheese (Beyaz peynir in Turkish) is almost similar to the cheeses produced under names of Feta, Domiati, Teleme etc. in various countries (Walstra et al., 1999; Hayaloğlu et al., 2002). Ovine and caprine milks are primarily preferred in White cheese production in Turkey. However, since lactation periods of these two animals are short, bovine milk is commonly used to make White cheese in the last three decades. Similar situations have been reported in other countries (Aminifar et al., 2013). Depending on milk sources and processing conditions, quality properties of the cheese show a great variation (Oktar et al., 1996; Hayaloğlu et al., 2002; Temizkan et al., 2014).

Type of milk is as effective on typical properties of cheeses as production methods and enzyme system, which plays important role in ripening (Molina et al., 1999; Arslaner and Bakırc1, 2016). Differences in casein fractions in different kinds of milk affect the properties of cheeses (Guo et al., 2004; Moatsou and Govaris, 2011). Also variations in fatty acid composition of different kinds of milks change sensory properties of cheese (Boyazoglu and Morand-Fehr, 2001; Basdagianni et al., 2019). The origin of the milk has a great effect on taste and flavor especially in ripened cheeses. Also, the color of the cheese is affected by milk origin. For example, bovine milk contains higher amounts of $\beta$-carotene and this makes the cheese yellowish. On the other hand, since caprine milk has higher amount of vitamin A, the color of caprine cheese appears whiter than those of bovine cheese (IDF, 1996; Kosikowski and Mistry, 1997).

Quality of cheese is greatly affected by peptides, amino acids and free fatty acids as a result of proteolysis and lipolysis. Proteolysis is the most effective biochemical phenomenon on taste-flavor and texture as in the other cheeses (Çakmakçı and Kurt, 1993). Proteolysis in cheeses is generally controlled by plasmin, chymosin, proteinases and peptidases from starter and non-starter culture, $\mathrm{pH}$ and temperature of the medium, moisture and salt content of the cheese and ripening time (Lawrence et al., 1987; Fox, 1989).

This study was aimed to compare the physicochemical, chemical and electrophoretic properties of White cheeses produced from bovine, ovine and caprine milks. Sensory properties of the cheeses from different origins of the milk were also compared at the end of the ripening period.

\section{Materials}

\subsection{Cheese Making}

For cheese making, bovine milk, ovine milk (Norduz variety of Akkaraman breed) and caprine milk (Domestic hairy goats) were obtained from milk processing plant of Agricultural College of Yüzüncü Yil University. No standardization was made in the milks. After the milks were clarified, they were pasteurized at $65{ }^{\circ} \mathrm{C}$ for $20 \mathrm{~min}$ and cooled to $32{ }^{\circ} \mathrm{C} . \mathrm{CaCl}_{2}$ was added to the milk at level of $0.15 \mathrm{~g} / \mathrm{l}$. Direct vat lyophilized starter cultures (Lactococcus lactis subsp. lactis and Lactococcus lactis subsp. cremoris; Rhodia Food, France) were used in the study. The milks with the cultures were set for $30 \mathrm{~min}$. Then, calf rennet (1:12000 strength; Pinar, Inc., Istanbul Turkey) was added into the milks so that coagulation takes place within $90 \mathrm{~min}$. The volumes of rennet were as follows: $6 \mathrm{~mL} / 100 \mathrm{~L}$ bovine milk, $5.2 \mathrm{~mL} / 100$ $\mathrm{L}$ caprine milk and $8.7 \mathrm{~mL} / 100 \mathrm{~L}$ ovine milk. After coagulation took place, the curd was cut into about $1-2 \mathrm{~cm}^{3}$ cubes and set for $15 \mathrm{~min}$ to remove 
some of the whey. The curds were transferred into the cheese clothes and set $15 \mathrm{~min}$. They were then pressed for $3 \mathrm{~h}$ to remove the whey. When the amount of separated whey decreased, pressure application was terminated. The curds were cut into the blocks and placed into the brine (containing $14 \mathrm{~g}$ salt $/ 100 \mathrm{~mL}$ water) and held for 8 $\mathrm{h}$. The salted cheeses were then placed into the plastic cases and filled up with the brine $(12 \mathrm{~g}$ $\mathrm{NaCl} / 100 \mathrm{~mL}$ ) (Hayaloğlu et al., 2002). The cheeses were stored at $8 \pm 1{ }^{\circ} \mathrm{C}$ for 180 days. The analyses were done on days $3,30,60,120$ and 180 . The study was repeated twice.

\section{Methods}

\subsection{Yield Determination}

Yield of cheese was calculated as the actual amount of cheese made per $100 \mathrm{~kg}$ of cheese milk. Then, the obtained values were converted into 58 $\%$ moisture and $3.0 \%$ salt-adjusted yield (Metzger and Mistry, 1994).

\subsection{Chemical Analyses}

Total solids (TSs) by oven drying method, protein by Kjeldahl method, acidity by titration (AOAC, 1990), fat by Gerber (IDF, 1986) and $\mathrm{pH}$ by a $\mathrm{pH}$ meter (Kosikowski, 1982) were analyzed in the milk and cheese samples. Salt content of cheese samples was determined by titration with $\mathrm{AgNO}_{3}$ (AOAC, 1990).

\subsection{Biochemical Analyses}

Proteolysis was determined as water soluble nitrogen (WSN), non-protein nitrogen (NPN) and amino nitrogen. Water extraction for WSN, 12\% trichloroacetic acid (TCA) extraction for NPN and 5\% phosphotungstic acid (PTA) extraction for amino nitrogen were used (Bütikofer et al., 1993). Nitrogen determination $(\%)$ in the extracts was done with Kjeldahl method (AOAC, 1990). Acid degree value was measured and calculated as described in Jellema (1991) and the results were stated as ADV. All chemical, physicochemical and biochemical analyses were carried out in duplicate.

\subsection{Electrophoretic Analyses}

The casein bands were separated by the modified method of Creamer (1991), which was described in Tarakçı et al. (2004). Electrophoresis unit was Owl P10DS (NH, USA), and power unit was Consort (Consort E835, BE). Electrophoresis was applied for both samples taken from the first and the second repetition. A scanner was used to transfer the pictures of urea-PAGE gels onto the PC. Optical densities of $\beta$ - and $\alpha_{s}$-caseins were measured by computer software (Un-scan-it, Version, 5.1 for Windows, Orem, Utah, USA). The amount of proteins injected into each slot was taken into consideration for residual protein calculations. The optical values taken at the beginning of the ripening (on day 3) were accepted as 100, and the values obtained from the other analyses periods were proportioned and stated as \%.

\subsection{Sensory Analyses}

The cheese samples were evaluated by 8 trained panelists at the end of the ripening in terms of color-appearance, texture, smell and taste-flavor. Hedonic type of scale was used for the evaluation, and 1 as minimum and 9 as maximum were considered for the range of scoring (Aston et al., 1985).

\subsection{Statistical Analyses}

Analysis of variance was performed with a statistic software program and the differences were analyzed with Duncan's multiple comparison test (SAS, 1988).

\section{Results and Discussions}

\subsection{Composition of the Milks}

The contents of total solids (TSs), protein, fat, and $\mathrm{pH}$ of the milks used for cheese making are presented in Table 1. The contents (TSs, crude protein, fat) of the ovine milk were higher than those of bovine and caprine milks. Moreover, the components in caprine milk were higher than those of bovine milk. The composition of milk normally varies depending on the species and races (Metin, 1996). The components belong to the samples of bovine milk were among the accepted limits. The milks of caprine and ovine used in the study were taken between days 90 and 120 of lactation period. The values of TSs of caprine and ovine milks were similar to those given by Aganga et al. (2002). However, general composition of the caprine milk was found higher than Alpine goats (Fekadu et al., 2005).

\subsection{Cheese Yield}

The highest yield $(26.81 \pm 0.55 \%)$ was found in the cheeses obtained from ovine milk, and this 
was followed by caprine cheese $(18.97 \pm 0.24 \%)$ (Table 1). The lowest yield $(15.15 \pm 0.40)$ was found in the cheeses made from bovine milk. The cheese yields were affected especially from fat and protein contents of cheese milk (Guo et al., 2004). Rudan et al. (1999) demonstrated that the yield of Mozzarella cheese of 5\% fat was 30\% lower than that of a cheese of $25 \%$ fat. In a study on Kashar cheese, the yields of cheeses made with ovine milk were found higher than caprine and bovine milk cheeses (Temizkan et al., 2014).

Table 1. Some properties of the milks and the yields of the cheeses

\begin{tabular}{lcccc}
\hline Dependent variables & $\mathrm{n}$ & Bovine milk & Caprine milk* $^{*}$ & Ovine milk* $^{*}$ \\
\hline Total solids (\%) & 2 & $12.82 \pm 0.05^{\mathrm{c}}$ & $14.32 \pm 0.19^{\mathrm{b}}$ & $18.10 \pm 0.36^{\mathrm{a}}$ \\
Protein (\%) & 2 & $3.31 \pm 0.04^{\mathrm{c}}$ & $3.76 \pm 0.05^{\mathrm{b}}$ & $5.77 \pm 0.06^{\mathrm{a}}$ \\
Fat (\%) & 2 & $3.92 \pm 0.03^{\mathrm{c}}$ & $5.45 \pm 0.07^{\mathrm{b}}$ & $7.1 \pm 0.14^{\mathrm{a}}$ \\
pH & 2 & $6.62 \pm 0.02^{\mathrm{b}}$ & $6.71 \pm 0.03^{\mathrm{ab}}$ & $6.72 \pm 0.02^{\mathrm{a}}$ \\
Cheese yield $(\%)^{* *}$ & 2 & $15.15 \pm 0.40^{\mathrm{c}}$ & $18.97 \pm 0.24^{\mathrm{b}}$ & $26.81 \pm 0.55^{\mathrm{a}}$
\end{tabular}

*: Samples were taken from lactation period between 90 and 120 days, **: Moisture-adjusted yield $=($ actual yield $(\%) \times[100$-(actual percentages of moisture and salt)] / [100-(desired percentages of moisture and salt)] n: number of the samples analyzed. ${ }^{a, b, c}$ : Means bearing different letters and given in the same row differ from each other statistically $(\mathrm{p}<0.05)$

\subsection{Chemical Changes of Cheeses}

The TSs content of cheeses increased at low levels from beginning up to 60 days of the ripening period, and then this increase remained almost constant or decreased slightly (Table 2). Increase in TSs might be because of salt diffusion from brine to cheese mass in the early stages of ripening. More syneresis occurs due to low $\mathrm{pH}$ and more whey is removed from the cheese mass. This eventually leads to an increase in TSs (Walstra et al., 1999). Decrease at the end of the ripening might be because of diffusing more brine into cheese mass in which casein matrix become weaker due to proteolysis and because of diffusing some of the products from cheese mass into the brine. TSs contents were not affected by the milks of different species statistically $(\mathrm{p}>0.05)$.

Mean values of fat contents of the cheeses were found to be different from each other $(\mathrm{p}<0.05)$. On the other hand, the protein content of caprine cheese was found to be significantly lower than the protein content of bovine and ovine cheeses ( $p$ $<0.01$ ), whereas there was no significant difference between the protein content of cow and sheep cheeses $(p>0.05)$. Since no standardization was made for fat content in milks, the original cheese-constituents contents of the milks reflected on the fat and protein contents of the cheeses. The highest protein / fat ratio was found in the bovine milk cheese (mean 0.688), and this was followed by ovine cheese (mean 0.644). The lowest (mean 0.605 ) value was obtained from the caprine milk cheese. The ratios of protein / fat of the cheese samples differed from each other significantly ( $\mathrm{p}$ $<0.01$ ). While fat contents of the cheeses showed a similar trend as in TSs contents during ripening, protein values in general continuously decreased after day 30 (Table 2). The main reason for protein decrease in the cheeses could be diffusing of small molecules from cheese into brine, which were formed as a result of proteolysis (Tunçtürk et al., 2003). Protein contents of the cheeses made from ovine and caprine milks decreased more than that of bovine milk cheese. The similar result was reported by Papademas and Robinson (2000) for Halloumi cheese made from ovine milk. The proportion of protein/fat ratios of the cheeses showed that proteolysis was more active in the ovine and caprine cheeses. Protein/fat ratio decreased in the cheeses during ripening, however, this was more evident for the ovine and caprine cheeses (Table 2).

No significant differences were found between salt contents of the cheeses. The content increased at the beginning of ripening, which might be due to the diffusion from brine to cheese mass. 
Table 2. The chemical and physicochemical properties of the cheeses $(n=2)$

\begin{tabular}{|c|c|c|c|c|}
\hline & \multirow[b]{2}{*}{$\begin{array}{c}\text { Ripening } \\
\text { time (days) }\end{array}$} & \multicolumn{3}{|c|}{ Cheese types } \\
\hline & & $\begin{array}{c}\text { Bovine milk } \\
\text { cheese }\end{array}$ & $\begin{array}{c}\text { Caprine milk } \\
\text { cheese }\end{array}$ & $\begin{array}{c}\text { Ovine milk } \\
\text { cheese }\end{array}$ \\
\hline \multirow[t]{6}{*}{ Total solids (\%) } & 3 & $42.94 \pm 0.43$ & $42.35 \pm 1.11$ & $42.74 \pm 1.10$ \\
\hline & 30 & $44.34 \pm 1.81$ & $43.15 \pm 1.37$ & $44.71 \pm 0.61$ \\
\hline & 60 & $43.98 \pm 1.83$ & $45.11 \pm 0.94$ & $44.85 \pm 1.73$ \\
\hline & 120 & $43.98 \pm 1.60$ & $44.03 \pm 1.98$ & $44.10 \pm 0.05$ \\
\hline & 180 & $43.79 \pm 0.62$ & $42.11 \pm 1.65$ & $43.29 \pm 1.76$ \\
\hline & Mean value & $43.79 \pm 0.62$ & $43.35 \pm 1.59$ & $43.94 \pm 1.26$ \\
\hline \multirow[t]{6}{*}{ Fat $(\%)$} & 3 & $22.50 \pm 0.70$ & $23.50 \pm 0.70$ & $22.75 \pm 1.06$ \\
\hline & 30 & $22.87 \pm 0.88$ & $24.00 \pm 0.70$ & $24.12 \pm 0.17$ \\
\hline & 60 & $22.75 \pm 1.06$ & $24.50 \pm 0.70$ & $23.75 \pm 1.06$ \\
\hline & 120 & $22.75 \pm 1.06$ & $24.50 \pm 1.41$ & $23.75 \pm 0.35$ \\
\hline & 180 & $23.00 \pm 0.70$ & $23.50 \pm 1.41$ & $23.25 \pm 1.06$ \\
\hline & Mean value & $22.77 \pm 0.69 b$ & $24.00 \pm 0.91 \mathrm{a}$ & $23.52 \pm 0.80 \mathrm{ab}$ \\
\hline \multirow[t]{6}{*}{ Protein $(\%)$} & 3 & $15.73 \pm 0.43$ & $14.76 \pm 0.02$ & $15.20 \pm 0.50$ \\
\hline & 30 & $16.30 \pm 0.49$ & $14.96 \pm 0.96$ & $16.08 \pm 0.05$ \\
\hline & 60 & $15.87 \pm 0.84$ & $15.10 \pm 0.35$ & $15.31 \pm 0.24$ \\
\hline & 120 & $15.34 \pm 0.27$ & $14.36 \pm 0.96$ & $14.95 \pm 0.29$ \\
\hline & 180 & $15.12 \pm 0.36$ & $13.51 \pm 0.45$ & $14.25 \pm 1.11$ \\
\hline & Mean value & $15.67 \pm 0.58 \mathrm{a}$ & $14.54 \pm 0.77 \mathrm{~b}$ & $15.15 \pm 0.75 \mathrm{a}$ \\
\hline \multirow[t]{6}{*}{ Protein/fat } & 3 & $0.699 \pm 0.002 \mathrm{a}$ & $0.628 \pm 0.019 b$ & $0.668 \pm 0.008 \mathrm{a}$ \\
\hline & 30 & $0.712 \pm 0.005 \mathrm{a}$ & $0.622 \pm 0.021 b$ & $0.666 \pm 0.007 b$ \\
\hline & 60 & $0.697 \pm 0.004 \mathrm{a}$ & $0.616 \pm 0.002 b$ & $0.644 \pm 0.019 b$ \\
\hline & 120 & $0.674 \pm 0.019 \mathrm{a}$ & $0.586 \pm 0.005 \mathrm{c}$ & $0.629 \pm 0.002 b$ \\
\hline & 180 & $0.657 \pm 0.004 \mathrm{a}$ & $0.575 \pm 0.015 \mathrm{c}$ & $0.612 \pm 0.019 b$ \\
\hline & Mean value & $0.688 \pm 0.021 \mathrm{a}$ & $0.605 \pm 0.025 \mathrm{c}$ & $0.644 \pm 0.024 b$ \\
\hline \multirow[t]{6}{*}{ Salt (\%) } & 3 & $2.94 \pm 0.13$ & $2.81 \pm 0.20$ & $3.05 \pm 0.21$ \\
\hline & 30 & $3.89 \pm 0.21$ & $3.86 \pm 0.33$ & $3.79 \pm 0.34$ \\
\hline & 60 & $3.87 \pm 0.10$ & $3.67 \pm 0.31$ & $3.78 \pm 0.19$ \\
\hline & 120 & $3.97 \pm 0.24$ & $3.64 \pm 0.13$ & $3.71 \pm 0.09$ \\
\hline & 180 & $3.72 \pm 0.11$ & $3.62 \pm 0.25$ & $3.80 \pm 0.36$ \\
\hline & Mean value & $3.68 \pm 0.41$ & $3.52 \pm 0.43$ & $3.62 \pm 0.36$ \\
\hline \multirow[t]{6}{*}{$\mathrm{pH}$} & 3 & $6.02 \pm 0.05$ & $6.05 \pm 0.12$ & $6.09 \pm 0.08$ \\
\hline & 30 & $5.56 \pm 0.16$ & $5.74 \pm 0.12$ & $5.76 \pm 0.10$ \\
\hline & 60 & $5.53 \pm 0.15$ & $5.70 \pm 0.08$ & $5.69 \pm 0.09$ \\
\hline & 120 & $5.51 \pm 0.15$ & $5.79 \pm 0.15$ & $5.79 \pm 0.12$ \\
\hline & 180 & $5.61 \pm 0.07 b$ & $5.89 \pm 0.09 a$ & $5.91 \pm 0.04 \mathrm{a}$ \\
\hline & Mean value & $5.64 \pm 0.22 b$ & $5.83 \pm 0.15 \mathrm{a}$ & $5.85 \pm 0.16 \mathrm{a}$ \\
\hline \multirow{6}{*}{$\begin{array}{l}\text { Titratable acidity } \\
\qquad(\%)\end{array}$} & 3 & $0.51 \pm 0.04$ & $0.59 \pm 0.04$ & $0.59 \pm 0.09$ \\
\hline & 30 & $0.81 \pm 0.04$ & $0.84 \pm 0.10$ & $0.91 \pm 0.04$ \\
\hline & 60 & $0.83 \pm 0.10$ & $0.79 \pm 0.12$ & $0.80 \pm 0.03$ \\
\hline & 120 & $0.90 \pm 0.02$ & $0.81 \pm 0.07$ & $0.87 \pm 0.14$ \\
\hline & 180 & $0.86 \pm 0.09$ & $0.80 \pm 0.09$ & $0.85 \pm 0.04$ \\
\hline & Mean value & $0.78 \pm 0.15$ & $0.77 \pm 0.11$ & $0.80 \pm 0.13$ \\
\hline
\end{tabular}

$\overline{\mathrm{a}, \mathrm{b}, \mathrm{c}}$ : Means bearing different letters and given in the same row differ from each other statistically $(\mathrm{p}<0.05)$.

The $\mathrm{pH}$ value of bovine cheese was different from caprine and ovine cheese at level of $p<0.05$. The cheeses of ovine and caprine milks had higher $\mathrm{pH}$ values than those of bovine cheeses (Table 2). This phenomena could be due to the assimilation of acidic molecules by some microorganisms (Schlesser et al., 1992), some molecules with basic character as a result of proteolysis (Walstra et al., 1999) and the effect of buffering structures of the molecules (Tunçtürk and Coşkun, 2002). The values of $\mathrm{pH}$ were higher in the cheeses made from ovine and caprine milks and had more proteolysis especially toward the end of the ripening. As is known, more amino groups are released by the breakdown of proteins, which further buffers dissociated hydrogen ions. Since the cheeses were matured using the same starter culture under the same conditions, there was no statistically difference between the acidity values of the cheeses $(p>0.05)$. Nespolo and Brandelli (2012) determined that cheese made from caprine milk had a higher fat content than Feta cheese 
made from ovine milk, and the $\mathrm{pH}$ value was reported as 5.89 in the 30th day of storage in caprine cheese. Cipolat-Gotet et al. (2016) found higher protein / fat ratio in cheeses made from bovine milk compared to cheese made from ovine milk, similar to our study.

\subsection{Biochemical Changes}

WSN values increased significantly in all cheeses for each analysis period ( $\mathrm{p}<0.05$ ). WSN values used as ripening index in cheese represent total proteolysis (Lopez-Fandino et al., 1991). In this fraction, low protein molecules, peptides and amino acids and further degradation products are available (Christensen et al., 1991).

Increase of WSN content was significantly higher in the ovine and caprine cheeses than the bovine cheeses at 120 and 180 days of ripening period $(\mathrm{p}<0.01)$ (Figure 1). Temizkan et al. (2014) found caprine cheeses had lower levels of soluble nitrogenous matters than those of bovine or ovine cheeses during ripening. Aminifar et al. (2013) reported higher WSN values in cheese from ovine milk compared with bovine milk cheese.

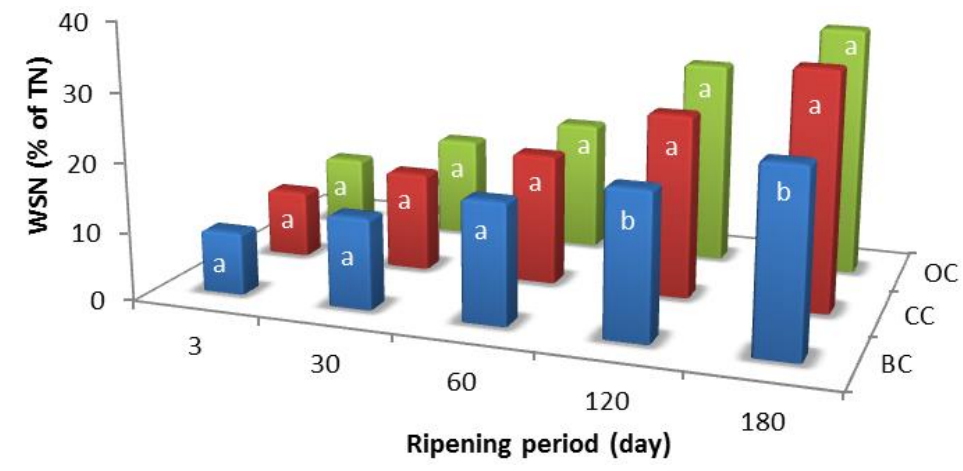

Figure 1. The changes in WSN values of the cheeses during ripening (BC: Bovine milk cheese, CC: Caprine milk cheese, OC: Ovine milk cheese. a,b,c: The means bearing different letters at the same ripening period differ from each other $(\mathrm{p}<0.05))$.
Only small peptides and amino acids are soluble in TCA-SN fraction (Yvon et al., 1989). Therefore, this fraction is called as non-protein nitrogen (NPN) (Farahat et al., 1985) and it is accepted as an index of proteinase activity in cheese (Lopez-Fandino and Ardö, 1991). TCASN values increased significantly in all cheeses for each analysis period as in WSN values (p $<0.05)$. The values of TCA-SN of the cheeses were similar until 60 days of ripening period $(\mathrm{p}$ $>0.05$ ), however then TCA values of ovine and caprine were found significantly higher than bovine cheese $(\mathrm{p}<0.01)$ (Figure 2$)$. It can be said that the factors affecting WSN values of the cheeses also affected TCA-SN values. Increases in TCA-SN may be due to the hydrolysis of high or medium molecular weight peptides to lower molecular weight peptides and amino acids (Hayaloglu et al., 2011). Values for TCA-SN and PTA-SN were higher in ovine Kashar cheeses than bovine or caprine Kashar cheeses during ripening $(\mathrm{P}<0.01)$ (Temizkan et al., 2014).

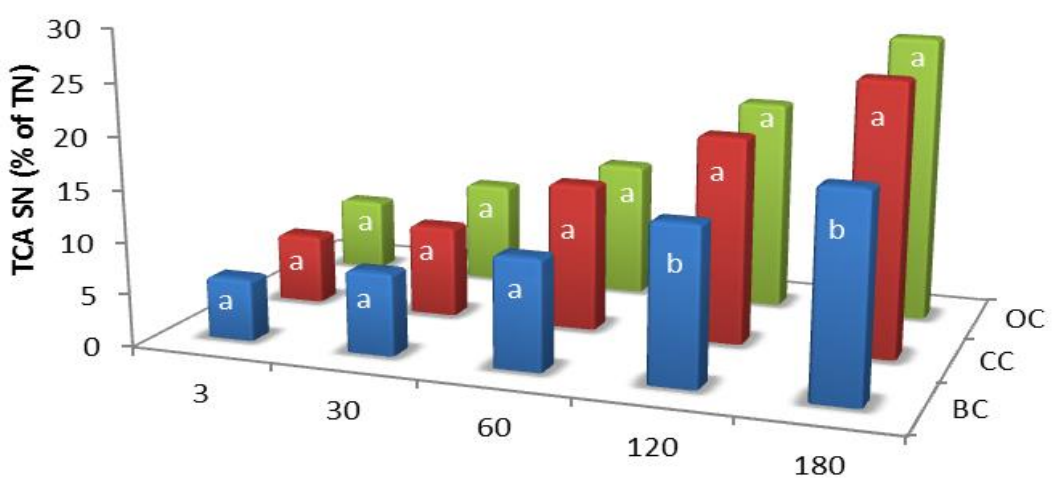

Ripening period (day)
4 Figure 2. The changes of TCA-SN values of the cheeses during ripening $(\mathrm{BC}$ : Bovine milk cheese, CC: Caprine milk cheese, OC: Ovine milk cheese. a,b,c: The means bearing different letters at the same period differ from each other $(\mathrm{p}<0.05))$.
Tri-, dipeptides, free amino acids and the other basic structured-degradation products are solved in PTA-SN fraction (Christensen et al., 1991; Fialaire and Postaire, 1994). PTA-SN values of the cheeses orderly increased during ripening.
PTA-SN values were found to be higher in the cheeses made from ovine and caprine milks than those of bovine milk cheeses, but the differences were not significant ( $>0.05)$ (Figure 3). 


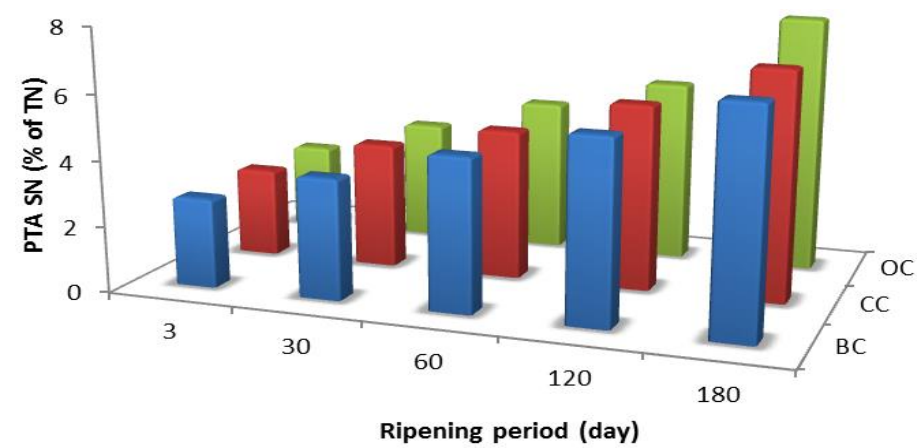

4 Figure 3. The changes of PTA-SN values of the cheeses during ripening (BC: Bovine milk cheese, CC: Caprine milk cheese, OC: Ovine milk cheese).
The reason behind of higher PTA-SN values in the ovine and caprine cheeses is that the substrates used by peptidases might be more effective in this kind of cheeses. As known, this fraction is formed by the peptidases released by starter cultures into the cheese medium as a result of autolysis. Thomas and Pritchard (1987) reported that lactic starter cultures secrete a number of proteinases and peptidases, and these have important function in cheese ripening and aroma development. In this study, since the same cultures were used, that no differences were obtained between the cheeses can be said.

The amount of rennet retained in the curd during drainage depends on many factors such as $\mathrm{pH}$ value during drainage and its added volume at the starting point (Lawrence et al., 1987; Kindstedt et al., 1995; Walstra et al., 1999). The use of higher amount of rennet per amount of ovine milk for cheese making and availability of higher amount of casein and fat (affecting on cheese total solids) in this milk might result with less amount of moisture removal during pressing or drainage and, therefore, higher amount of chymosin retention in the cheese mass. As a result of this, proteolysis by chymosin was found higher in ovine milk cheese. Kindstedt et al. (1995) reported that total proteolysis increased in the cheese if the volume of coagulation enzyme was increased. This result also explains the reason of higher proteolysis in the ovine milk cheeses. Papademas and Robinson (2000) found that proteolysis was higher in ovine milk cheeses than bovine milk cheeses. Although less amount of rennet was used for caprine milk cheeses than bovine milk cheeses in our study, higher proteolysis (especially in degradation of

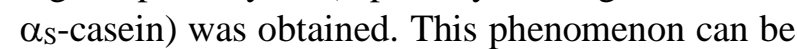
explained with higher retained amount of the rennet in the caprine milk curd or with sensitivity of caprine milk casein against the rennet than bovine milk casein. Güven et al. (1994) reported the similar results in Tulum cheeses.

Degradations of $\beta$ - and $\alpha_{S}$-casein in all cheeses constantly increased during ripening. In general,

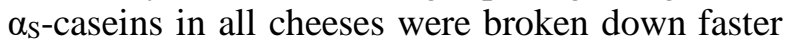
than $\beta$-caseins (Figure 4).

Both casein fractions degraded faster in ovine and caprine cheeses than bovine cheese $(p<0.01)$. At end of the ripening (on day 180), higher amount of intact $\beta$-casein $(71.52 \%)$ was found in bovine cheeses (Figure 5).

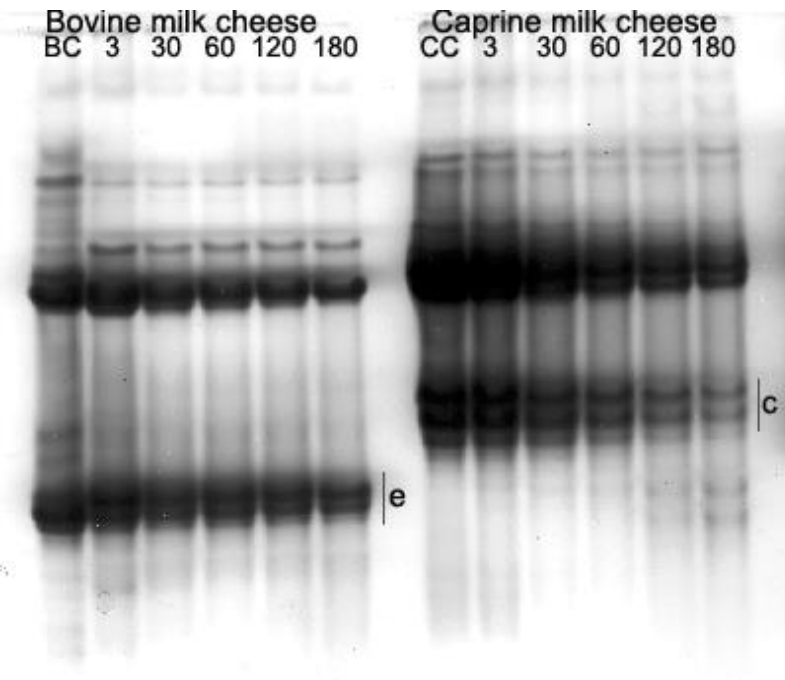

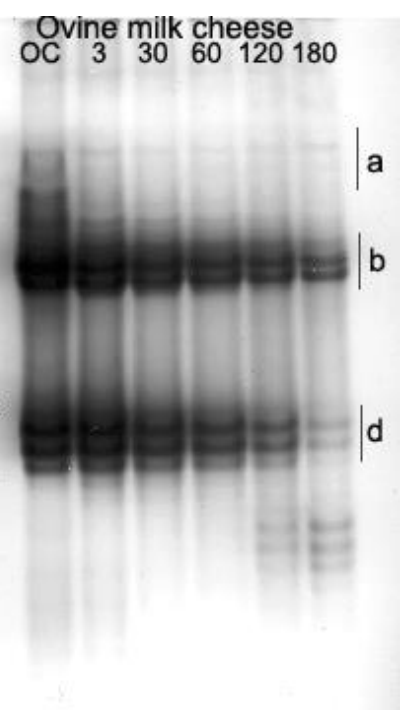

4 Figure 4.

Electropherograms of the caseins degradation of the cheeses made from bovine, ovine and caprine milks (BC: bovine caseins, OC: ovine caseins, CC: caprine caseins. 3, 30, 60, 120, 180: ripening days. a: $\gamma$ caseins, b: $\beta$-casein, $c$ : $\alpha_{S^{-}}$ caseins of caprine milk cheese, $d: \alpha_{\text {s-caseins of }}$ ovine milk cheese, e: $\alpha_{S^{-}}$ caseins of bovine milk cheese). 


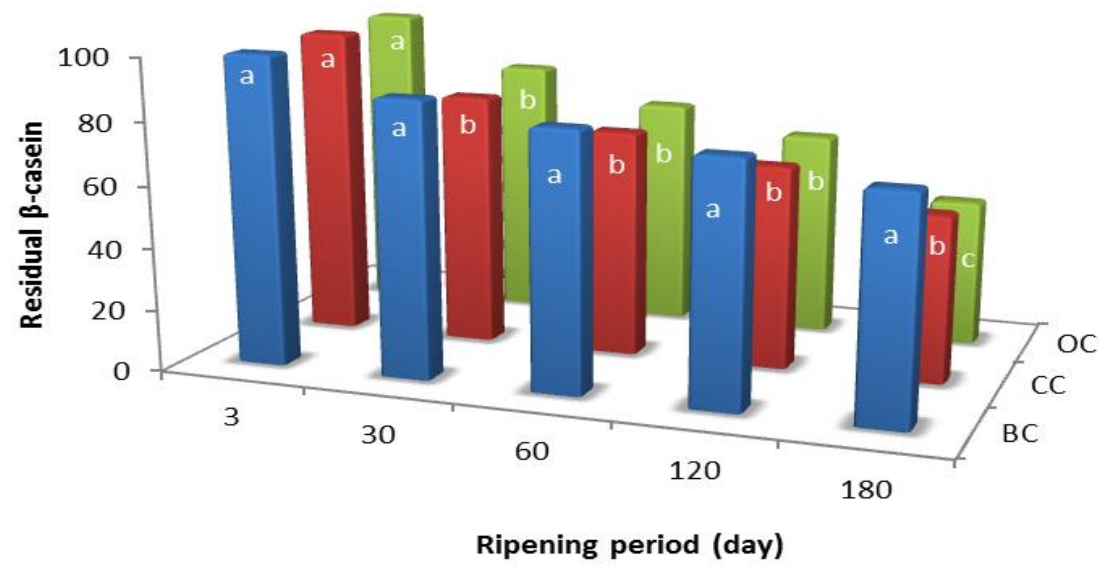

Figure 5. The changes in the residual $\beta$-caseins of the cheeses during ripening (BC: Bovine milk cheese, CC: Caprine milk cheese, OC: Ovine milk cheese. a,b,c The means bearing different letters at the same period differ from each other $(\mathrm{p}<0.05))$.

$\beta$-casein is mainly broken down by milk plasmin, and this enzyme found in the form of plasminogen associated with casein micelles is activated with different mechanisms (Barrett et al., 1999). Decrease in $\mathrm{pH}$ in cheese is effective in the activation of the enzyme (Lawrence et al., 1987). Park and Jin (1998) stated that rennet is able to degrade $\beta$-casein and form various peptides. In the study, higher degradation of $\beta$-casein in ovine and caprine cheeses might be because of the amount of remained rennet in the cheese mass and activation level of plasmin involved. Residual $\alpha_{S^{-}}$ casein ratio was higher in bovine cheeses. Intact $\alpha_{\mathrm{s}}$-caseins of the cheeses at the end of the ripening were as $66.26 \%$ in bovine cheese, $36.45 \%$ in caprine cheese and $24.48 \%$ in ovine cheese (Figure 6).

Chymosin amount retained in cheese mass plays the greatest role in hydrolysis of $\alpha_{\mathrm{S}}$-casein in the cheeses (Lawrence et al., 1987). Furthermore, the proteinases belong to cheese micro flora hydrolyze casein fractions even in less rate (Thomas and Pritchard, 1987).

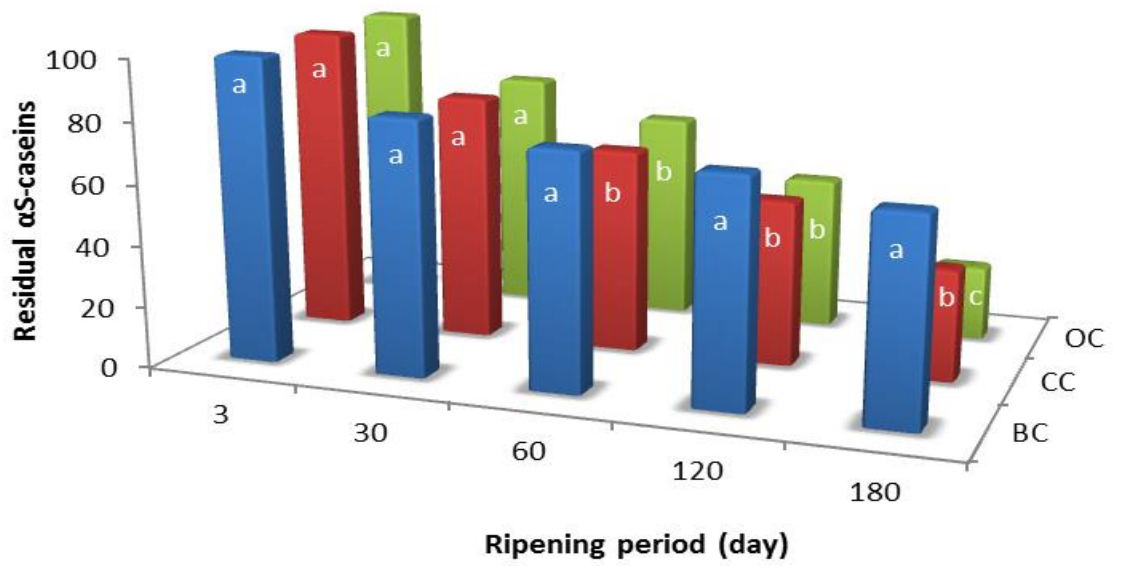

Figure 6. The changes in residual $\alpha_{s}$-casein of the cheeses during ripening (BC: Bovine milk cheese, CC: Caprine milk cheese, OC: Ovine milk cheese. a,b,c: The means bearing different letters at the same period differ from each other $(\mathrm{p}<0.05))$.

ADV values showing lipolysis degree in the cheeses increased during ripening. ADV values obtained from ovine and caprine cheeses were higher than those of bovine cheese from the beginning to end of the ripening, and which was at significant levels in days of 120 and 180 of storage $(\mathrm{p}<0.01)$. At the end of the ripening, ADV values of caprine cheeses were the highest (Figure
7). The fact that proteolysis and lipolysis values are higher than bovine cheese in ovine and caprine cheeses especially on the 120th and 180th days may be attributed to the fact that the milk from which these cheeses are made contains more and richer microflora than bovine milk even after pasteurization. 


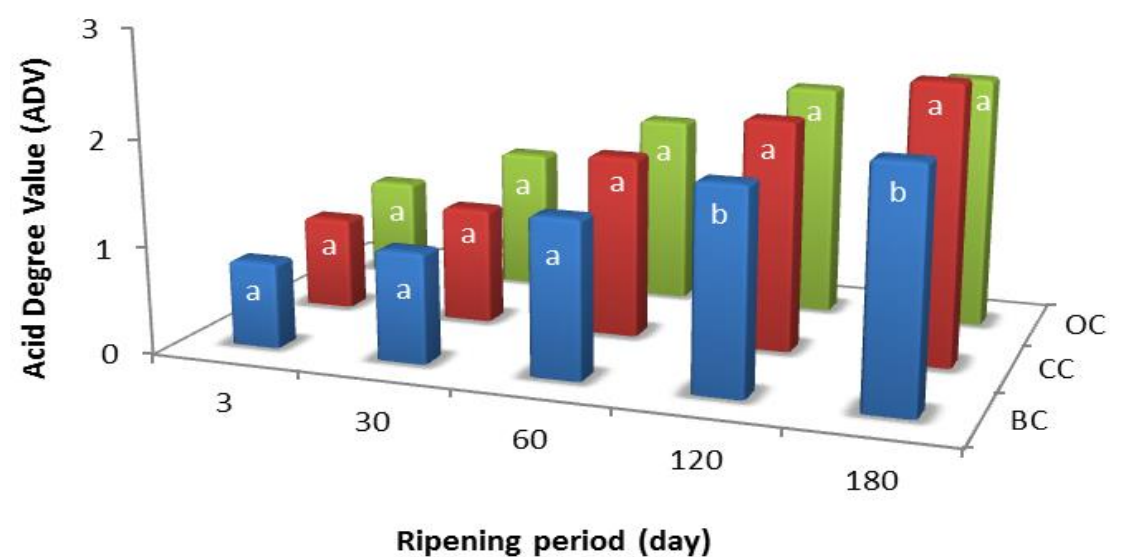

Figure 7. The changes in ADV values of cheeses during ripening (BC: Bovine milk cheese, $\mathrm{CC}$ : Caprine milk cheese, OC: Ovine milk cheese. a,b,c: The means bearing different letters at the same period differ from each other $(\mathrm{p}<0.05))$.

The highest ADV values in ovine and caprine cheeses showed that lipolytic activity was higher in these cheeses. Since the diameter of fat globules in caprine milk is small (Attaie and Richter, 2000; Coşkun and Öndül, 2004) and the surface area is bigger, these may be the reasons for higher lipolytic activity in caprine cheeses. Moreover, differences in the compositions of the milks from different species (Kosikowski and Mistry, 1997) might be effective on the lipolysis degree in the cheeses. Demiryol and Yaygin (1984) found the highest lipolysis in the cheeses made from caprine milk, which was followed by ovine and bovine milks with a high level. Fuente et al. (1993) reported the similar results. The later researchers suggested that the lipases which may be found in rennet can contribute lipolysis in cheeses.

\subsection{Sensorial Changes}

In terms of sensory properties, the most preferred cheeses were those that made from ovine milk, and this was followed by caprine cheeses (Figure 8).

There was no significant differences between color-appearance and texture scores of the cheeses ( $>0.05)$. However, the scores of taste and flavor of the cheeses were different from each other $(p<0.05)$. The color of the cheeses made from bovine milk was more yellowish than ovine and caprine cheeses. Usually the open-White color is preferred in the White-pickled cheese by the consumers. As known, bovine milk has higher amount of $\beta$-carotene when compared with the other milks, which makes the products more yellowish (Metin, 1996; Walstra et al., 1999). On the other hand, the color of the caprine cheese to be perceived whiter as a result of the transformation of $\beta$-carotene into colorless vitamin $\mathrm{A}$ and containing low diameter fat globules (Attaie and Richter, 2000; Coşkun and Öndül, 2004). High level of proteolysis and lipolysis in caprine and ovine cheese also affected the textural properties and other sensorial properties and therefore, these cheeses received higher scores. Some panelists reported that the bovine milk cheeses had thicker and drier structure than the others. Interestingly caprine cheeses received the highest score in terms of smell. The taste and flavor of the ovine cheeses were found more acceptable than the others, and this was followed by caprine cheese. Although the cheeses made from bovine milk were typical for the taste and flavor of the White-pickled cheese, they were found as tasteless when compared with the others. Some of the panelists reported spicy taste and flavor in the caprine cheeses. However, this taste was not unacceptable and gained the cheese a different taste. Higher amount of short chain fatty acids in the caprine cheeses might involve in such taste (Kosikowski and Mistry, 1997). In addition, higher proteolysis degrees in ovine and caprine cheeses may positively affect the sensory properties of the cheeses. Even if it was not significant statistically, amino nitrogen contents were higher in ovine and caprine cheeses. A highly correlation was reported between taste of cheese and this nitrogen fraction (Aston et al., 1983).

\section{Conclusion}

Ovine and caprine milks which have $10 \%$ proportion of total milk production in Turkey has an important potential in White-pickled cheese production in point of yield and quality. 


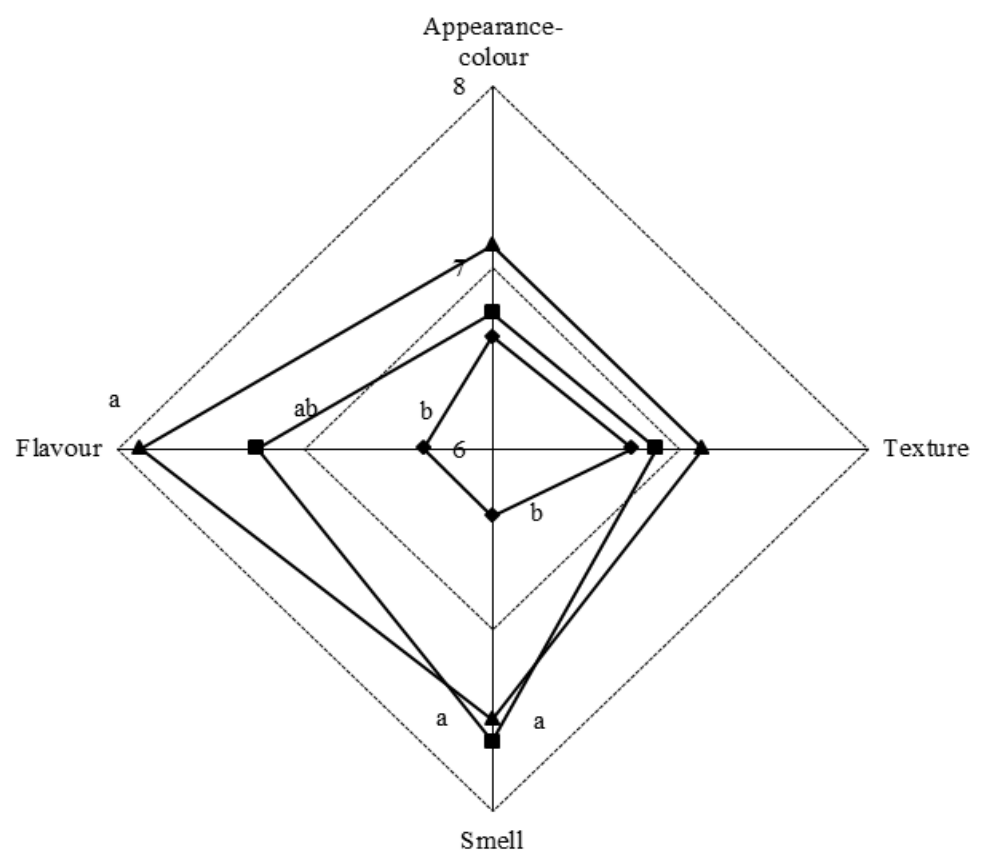

Figure 8. Sensory scores given by the panellists for the cheeses $\diamond$ Bovine milk cheese, - Caprine milk cheese, $\boldsymbol{\Delta}$ Ovine milk cheese. a, ab, b: The means bearing different letters at the same period differ from each other $(\mathrm{p}<0.05))$.

The use of milks pertaining to different species in the White cheese production affected the values of yield ( $\mathrm{p}<0.01)$, chemical compositions, biochemical, electrophoretic and sensory properties. From higher to lower, yield of cheeses were determined as ovine, caprine and bovine cheeses, respectively. Significant differences were determined in fat $(\mathrm{p}<0.05)$, protein $(\mathrm{p}<0.01)$ and cheese yield $(p<0.01)$ of White cheese samples. The results indicated that the ovine milk cheeses had higher amount of lipolysis and proteolysis. WSN and TCA-SN values were revealed to be higher in sheep and caprine cheeses than bovine cheeses $(p<0.01)$. Electrophoresis analysis also showed that more casein degradation occurred in ovine and caprine cheeses than bovine cheese. ADV values of caprine and ovine cheeses were also significantly higher than bovine cheese ( $p$ $<0.01$ ). The caprine cheeses had its typical and intensive taste and flavor. Because of that, if the characteristics of bovine milk cheeses are wanted to be improved, bovine milk may be mixed with caprine milk, and this case, of course, should be indicated in the label exactly. In this study, it was also understood from the electrophoretic gels that any cheese that is made with a mixture of milks can be determined in certain (limited) levels to avoid adulteration.

\section{References}

Aganga, A.A., Amarteifio, J.O. and Nkile, N., 2002. Effect of Stage of Lactation on Nutrient
Composition of Tswana Sheep and Goat's Milk. Journal of Food Composition and Analysis, 15, 533-543.

Aminifar, M., Hamedi, M., Emam-Djomeh, Z. and Mehdinia, A., 2013. The Effect of Ovine and Bovine Milk on the Textural Properties of Lighvan Cheese During Ripening. International Journal of Dairy Technology, 66(1), 45-53.

Arslaner, A. and Bakırcı, İ., 2016. Effect of Milk Type, Pasteurization and Packaging Materials on Some Physicochemical Properties and Free Fatty Acid Profiles of Tulum Cheese. Akademi Gida, 2, 98-104.

AOAC, 1990. Official Methods of Analysis, 15th Edition. Association of Official Analysis Chemists, Washington DC.

Aston, J.W., Durward, I.G. and Dulley, J.R. 1983. Proteolysis and Flavor Development in Cheddar Cheese. The Australian Journal of Dairy Technology, 38, 55-58.

Aston, J.W., Giles, J.E., Durward, I.G. and Dulley, J.R. 1985. Effect of Elevated Ripening Temperatures on Proteolysis and Flavour Development in Cheddar Cheese. Journal of Dairy Research, 52, 565-572.

Attaie, R. and Richter, R.L., 2000. Size Distribution of Fat Globules in Goat Milk. Journal of Dairy Science, 83, 940-944.

Barrett, F.M., Kelly, A.L., McSweeney, P.L.H. and Fox, P.F. 1999. Use of Exogenous Urokinase to 
Accelarete Proteolysis in Cheddar Cheese During Ripening. International Dairy Journal, 9, 421-427.

Basdagianni, Z., Papaloukas, L., Kyriakou, G., Karaiskou, C., Parissi, Z., Sinapis, E. and Kasapidou, E., 2019. A Comparative Study of the Fatty Acid and Terpene Profiles of Ovine and Caprine Milk from Greek Mountain Sheep Breeds and a Local Goat Breed Raised Under a Semi-Extensive Production System. Food Chemistry, 278, 625-629.

Boyazoglu, J., 2002. Livestock Research and Environmental Sustainability with Special Reference to the Mediterranean Basin. Small Ruminant Research, 45, 193-200.

Boyazoglu, J. and Morand-Fehr, P., 2001. Mediterranean Dairy Sheep and Goat Products and Their Quality A Critical Review. Small Ruminant Research, 40, 1-11.

Bütikofer, U., Ruegg, M. and Ardö, Y., 1993. Determination of Nitrogen Francions in Cheese: Evalluation of a Collaborative Study. Lebensmittel Wissenchaft und Technologie, 26(3), 271-275.

Çakmakçı, S. and Kurt, A., 1993. Salamura Tuz Oranı ve Olgunlaşma Süresinin $\mathrm{CaCl} 2$ ve lesitin İlavesiyle Üretilen Beyaz Salamura Peynir Kalitesine Etkisi. The Journal of Food, 18(1), 21-28.

Christensen, T.M.I.E., Bech, A.M. and Werner, H., 1991. Methods for Crude Fractionation (Extraction and Precipitation) of Nitrogen Components in Cheese. Bulletin of the IDF, 261, 4-9.

Cipolat-Gotet, C., Cecchinato, A., Pazzola, M., Dettori, M.L., Bittante, G. and Vacca, G.M., 2016. Potential Influence of Herd and Animal Factors on Yield of Cheese and Recovery of Components from Sarda Sheep Milk, as Determined by a Laboratory Bench-Top Model Cheese-Making. International Dairy Journal, 63, 8-17.

Coşkun, H. and Öndül, E., 2004. Keçi Sütü ve İnsan Beslenmesindeki Önemi. Türkiye 8. G1da Kongresi 26-28 Mayıs, Bursa, Turkey. s.70.

Creamer, L.K. 1991. Electrophoresis of cheese. Bulletin of the IDF, 261, 14-28.

Demiryol, I. ve Yaygın, H., 1984. İnek, Koyun ve Keçi Sütlerinden Yapılan ve Farklı Sicaklıklarda Olgunlaştırılan Beyaz Peynirlerin Özellikleri Üzerinde Araştırmalar. Journal of Agriculture Faculty of Ege University, 21 (3), 127-140.
FAO, 2019. http://www.fao.org/dairy-productionproducts/production/en/ 14 September 2019.

Farahat, S.M., Rabie, A.M., Abdel Baky, A.A., ElNeshawy, A.A. and Mobasher, S., 1985. $\square$ Galaktozidase in the Acceleration of Ras Cheese Ripening. Die Nahrung, 29(3), 247-254.

Fekadu, B., Soryal, K., Zeng, S., Van Hekken, D., Bah, B. and Villaquiran, M., 2005. Changes in Goat Milk Composition During Lactation and Their Effect on Yield and Quality of Hard and SemiHard Cheeses. Small Ruminant Research, 59, 55-63.

Fialaire, A. and Postaire, E., 1994. Hydrolysis of Peptide Binding by Phosphotungstic Acid. Journal of AOAC International, 77(5), 13381340.

Fox, P.F., 1989. Proteolysis During Cheese Manufacture and Ripening. Journal of Dairy Science, 72, 1379-1408.

Fuente, M.A., Fontecha, J. and Juárez, M., 1993. Fatty Acid Composition of the Triglyceride and Free Fatty Acid Fractions in Different Cows-, Ewesand Goats-Milk Cheeses. Zeitschrift Für Lebensmittel-Untersuchung und-Forschung, 196, 155-158.

Guo, M., Park, Y.W., Dixon, P.H., Gilmore, J. A, Kindstedt Paul, S., 2004. Relationship Between the Yield of Cheese (Chevre) and Chemical Composition of Goat Milk. Small Ruminant Research, 52, 103-107.

Güven, M., Konar, A. and Kleeberger, A., 1994. İnek, Koyun ve Keçi Sütlerinden Yapılan ve Deri tulumlarda Olgunlaştırılan Tulum Peynirlerinin Fiziksel, Kimyasal ve Duyusal Özellikleri. Çukurova Journal of Agricultural and Food Sciences, 25th Anniversary Special Issue, 203218.

Hayaloğlu, A., Güven, M. and Fox, P.F. 2002. Microbiological, Biochemical and Technological Properties of Turkish White Cheese "Beyaz Peynir". International Dairy Journal, 12, 635-648.

IDF (International Dairy Federation), 1986. Cheese and Processed Cheese Products. Determination of Fat Contents. IDF Standard 5B. Brussels. BE.

Jellema, A., Anderson, M., Heeschen, W., KuzdalSavoie, S., Needs, E.C., Suhren, G., Van Reusel, A., 1991. Determination of free fatty acids in milk and milk products. Bulletin of the International Dairy Federation no. 265.

Kindstedt, P.S., Yun, J.J., Barbano, D.M. and Larose, K.L., 1995. Mozzeralla Cheese: Impact of Coagulant Concentration on Chemical 
Composition, Proteolysis, and Functional Properties. Journal of Dairy Science, 78, 25912597.

Kosikowski, F.V. and Mistry, V.V., 1997. Cheese and Fermented Milk Foods, Vol. 1. Westport CT 06880: F V Kosikowski LLC, 729 p.

Kosikowski, F.V., 1982. Cheese and Fermented Milk Foods, Published by F V Kosikowski and Associates New York, 711p.

Lawrence, R.C., Creamer, L.K. and Gilles, J., 1987. Texture Development During Cheese Ripening, Journal of Dairy Science, 70, 1748-1760.

Lopez-Fandino, R. and Ardö, Y., 1991. Effect of Heat Treatment on the Proteolytic/Peptidolytic Enzyme System of a Lactobacillus delbrueckii subsp. bulgaricus Strain, Journal of Dairy Research, 58, 469-475.

Lopez-Fandino, R., Ramos, M., Fernandez-Garcia, E. and Olano, A., 1991. Proteolytic Activity of Two Commercial Proteinases From Aspergillus oryzae and Bacillus subtilis on Ovine and Bovine Caseins. Journal of Dairy Research, 58, 461-467.

Metin, M., 1996. Süt Teknolojisi: Sütün Bileşimi ve İşlenmesi (Dairy Technolgy: Composition and Process), Ege Üniversitesi Mühendislik Fakültesi Yayın 33. İzmir Turkey, 793 p.

Metzger, L.E. and Mistry, V.V., 1994. A New Approach Using Homogenization of Cream in the Manufacture of Reduced Fat Cheddar Cheese. 1. Manufacture, Composition, and Yield. Journal of Dairy Science, 77, 3506-3515.

Moatsou, G. and Govaris, A., 2011. White Brined Cheeses: A Diachronic Exploitation of Small Ruminants Milk in Greece. Small Ruminant Research, 101, 113-121.

Molina, E., Ramos, M., Alonso, L. and López-Fandiño, R., 1999. Contribution of Low Molecular Weight Water Soluble Compounds to the Taste of Cheeses Made of Cows', Ewes' and Goats' Milk. International Dairy Journal, 9, 613-621.

Nespolo, C.R. and Brandelli, A., 2012. Characterization of Cheeses Produced With Ovine and Caprine Milk and Microbiological Evaluation of Processing Areas in the Dairy Plant in Brazil. International Food Research Journal, 19(4), 1713-1721.

Oktar, E., Gönç, S. and Akalın, S., 1996. Peynir Teknolojisinde Kazan Sütüne Yapılacak Ön İşlemler. Her Yönüyle Peynir. M Demirci (Eds), İstanbul, Turkey, Hasad Publication. p. 50-65.
Papademas P and Robinson R.K., 2000. A Comparison of the Chemical, Microbiological and Sensory Characteristics of Bovine and Ovine Halloumi Cheese. International Dairy Journal, 10, 761768.

Park, Y.W. and Jin, Y.K., 1998. Proteolytic Patterns of Caciotta and Monterey Jack Hard Goat Milk Cheeses as Evaluated by SDS-PAGE and Densitometric Analyses. Small Ruminant Research, 28, 263-272.

Pirisi, A., Comunian, R., Urgeghe, P.P. and Scintu, M.F., 2011. Sheep's and Goat's Dairy Products in Italy: Technologycal, Chemical, Microbiological and Sensory Aspects. Small Ruminant Research, 101, 102-112.

Rudan, M.A., Barbano, D.M., Yun, J.J. and Kindstedt, P.S., 1999. Effect of Fat Reduction on Chemical Composition, Proteolysis, Functionality, and Yield of Mozzarella Cheese. Journal of Dairy Science, 82, 661-672.

SAS® 1988. User's Guide, Statistics SAS Institute Inc. Carry, NC, USA.

Schlesser, J.E., Schmidt, S.J. and Speckman, R., 1992. Characterization of Chemical and Physical Changes in Camambert Cheese During Ripening. Journal of Dairy Science, 75, 17531760.

Stocco, G., Pazzola, M., Dettori, M.L., Paschino, P., Bittante, G. And Vacca, G.M., 2018. Effect of Composition on Coagulation, Curd Firming and Syneresis of Goat Milk. Journal of Dairy Science, 101, 9693-9702.

Şimşek, Ü.G., Bayraktar, M. and Gürses, M., 2006. Çiftlik Koşullarında Kıl Keçilerine Ait Bazı Verim Özelliklerinin Araştırılması. Fırat Üniversitesi, Sağlık Bilimleri Veteriner Dergisi, 20, (3), 221-227.

Tarakçı, Z., Coşkun, H. and Tunçtürk, Y. 2004. Some Properties of Fresh and Ripened Herby Cheese, a Traditional Variety Produced in Turkey. Food Technology and Biotechnology, 42(1), 47-50.

Temizkan, R., Yaşar, K. and Hayaloğlu, A.A., 2014. Changes During Ripening in Chemical Composition, Proteolysis, Volatile Composition and Texture in Kashar Cheese Made Using Bovine, Ovine or Caprine Milk. International Journal of Food Science and Technology, 49, 2643-2649.

Thomas, T.D. and Pritchard, G.G., 1987. Proteolytic Enzymes of Dairy Starter Cultures. FEMS Microbiology Reviews, 46, 245-268.

Tunçtürk, Y. and Coşkun, H., 2002. The Effects of Production and Ripening Methods on Some 
Properties of Herby Cheese (Otlu Peynir). Milchwissenschaft, 57(11/12), 638-640

Tunçtürk, Y., Coşkun, H. and Ghosh, B.C., 2003. Nitrogen Fractions in Brine During Ripening of Herby Cheese (Otlu Peynir). Indian Journal of Dairy Science, 56(4), 208-212.

\section{URL-1}

http://www.turkstat.gov.tr/PreHaberBultenleri.d o? id=30728. 10 September 2019.

Yıldız, N. and Denk, H., 2006. Van Bölgesinde Halk Elinde Yetiştirilen Akkaraman Koyunlarda
Çeşitli Verim Özellikleri I. Döl ve Süt Verimi Özellikleri. Fırat Üniversitesi, Sağlık Bilimleri Veteriner Dergisi, 20, (1), 21-27.

Walstra, P., Geurts, T.J., Noomen, A., Jellema, A. and Van Boekel, M.A.J.S., 1999. Dairy Technology: Principles of Milk, Properties and Processes Marcel Dekker Inc. New York-Basel, 726 p.

Yvon, M., Chabanet, C. and Pelissier, J.P., 1989. Solubility of Peptides in Trichloroacetic Acid (TCA) Solutions. International Journal of Peptide and Protein Research, 34, 166-176. 